\title{
Title: Biostimulation of Iron Reduction and Uranium Immobilization: Microbial and Mineralogical Controls
}

Project ID: 0006114

Prog Mgr: $\quad$ Robert T. Anderson Phone: 301-903-5549 Division: SC-23.4

PI: Joel E. Kostka

Award Register\#: ER62986 0006114

\section{Summary of Project Results}

This project represented a joint effort between Florida State University (FSU), Rutgers University (RU), and the University of Illinois (U of I). FSU served as the lead institution and Dr. J.E. Kostka was responsible for project coordination, integration, and deliverables. This project was designed to elucidate the microbial ecology and geochemistry of metal reduction in subsurface environments at the U.S. DOE-NABIR Field Research Center at Oak Ridge, Tennessee (ORFRC). Our objectives were to: 1) characterize the dominant iron minerals and related geochemical parameters likely to limit $\mathrm{U}(\mathrm{VI})$ speciation, 2) directly quantify reaction rates and pathways of microbial respiration (terminal-electron-accepting) processes which control subsurface sediment chemistry, and 3 ) identify and enumerate the organisms mediating $\mathrm{U}(\mathrm{VI})$ transformation.

A total of 31 publications and 47 seminars or meeting presentations were completed under this project. One M.S. thesis (by Nadia North) and a Ph.D. dissertation (by Lainie PetrieEdwards) were completed at FSU during fall of 2003 and spring of 2005, respectively. Ph.D. students, Denise Akob and Thomas Gihring have continued the student involvement in this research since fall of 2004. All of the above FSU graduate students were heavily involved in the research, as evidenced by their regular attendance at PI meetings and ORFRC workshops.

Isolation and characterization of anaerobic metal-reducing prokaryotes (MRP). Using more traditional cultivation methods, novel strains from at least four MRP groups (Geobacter, Desulfotomaculum, Anaeromyxobacter, Clostridium) were isolated from the ORFRC subsurface. Several dissimilatory $\mathrm{Fe}(\mathrm{III})$-reducing isolates of Anaeromyxobacter were obtained in collaboration with Sara Thomas and Frank Loeffler (Georgia Tech), and these have yet to be extensively characterized. The Geobacter and Desulfotomaculum strains are physiologically distinct from close relatives. Desulfotomaculum-related strains 27C1 and 30205 were obtained from contaminated and background ORFRC sediment, respectively. Both utilize Fe(III) as well as sulfate as an electron acceptor and reduction of $\mathrm{FeOOH}$ was enhanced with AQDS as an electron shuttle. Isolates $27 \mathrm{C} 1$ and 30205 grew optimally with lactate and sulfate. Ethanol, hydrogen, lactate, and malate were utilized as electron donors. Geobacter strain FRC-32 was isolated from highly contaminated ORFRC subsurface sediments. FRC-32 utilized fumarate, elemental $\mathrm{S}$, and a variety of $\mathrm{Fe}(\mathrm{III})$ forms but not nitrate or sulfate as an electron acceptor. Of the 12 electron donors tested with $\mathrm{FeOOH}$, only ethanol, acetate, and formate were utilized. The draft genome sequence of Geobacter strain FRC-32 has been completed by the Joint Genome Institute and annotation is currently underway through collaboration with Dr. Derek Lovley at UMASS-Amherst.

Electron transport mechanisms and microbial diversity under near in situ conditions. In order to provide a further understanding of the coupled microbiological and geochemical processes limiting radionuclide bioremediation, we determined the rates and pathways of TEAPs in microcosm experiments using close to in situ conditions with ORFRC subsurface sediments and groundwater. Microcosms were constructed over a range of treatments and site materials (Edwards et al., 2007; Akob et al., 2007). In microcosms of highly contaminated ORFRC 
sediments at the in situ $\mathrm{pH}$ range of 4 to 5 , electron donor utilization and TEAP rates were diminished, such that nitrate was not depleted and metal reduction was prevented. Upon biostimulation by $\mathrm{pH}$ neutralization and carbon substrate addition, TEAPs were stimulated to rates that rival those measured in organic-rich surficial sediments of aquatic environments, and extremely high nitrate concentrations $(0.4$ to $0.5 \mathrm{M})$ were not found to be toxic to microbial metabolism (Edwards et al., 2007). Nitrate, Fe(III), and sulfate were the most abundant electron acceptors available for microorganisms and these were utilized in succession (Edwards et al., 2007; Akob et al., 2007). Under neutral pH conditions, $\mathrm{U}(\mathrm{VI})$ and $\mathrm{Fe}(\mathrm{III})$ were reduced concurrently once nitrate was depleted to low levels in response to biostimulation. Acidity controlled not only the rates but also the pathways of microbial activity. Denitrification predominated in sediments originating from neutral $\mathrm{pH}$ zones, while dissimilatory nitrate reduction to ammonium occurred in neutralized acidic microcosms amended with glucose. Electron donors were determined to stimulate microbial metabolism leading to metal reduction in the following order: glucose $>$ ethanol $>$ lactate $>$ hydrogen. In microcosms of neutralized acidic sediments, 80 to $90 \%$ of $\mathrm{C}$ equivalents were recovered as fermentation products, mainly as acetate. Due to the stress imposed by low $\mathrm{pH}$ on microbial metabolism, our results indicate that the TEAPs of acidic subsurface sediment inherently differ from those of neutral $\mathrm{pH}$ environments and neutralization will be necessary to achieve sufficient metabolic rates for radionuclide immobilization. Though evidence from microcosms points to certain nitrogen biotransformation pathways, direct rate measurements are needed to verify these under in situ conditions.

In Area 2 ORFRC materials ( $\mathrm{pH} \mathrm{6-7),} \mathrm{microbial} \mathrm{communities} \mathrm{were} \mathrm{characterized} \mathrm{in}$ parallel on freshly collected sediment cores and sediment microcosms. Using a most probable number (MPN) approach, Fe(III)-reducers and nitrate-reducers were shown to be 2 to 5 orders of magnitude more abundant in biostimulated microcosms in comparison to microcosm controls and sediment cores. From a comparison of MPN counts, nitrate-reducers appeared to outcompete $\mathrm{Fe}$ (III)-reducers in glucose and control treatments, while $\mathrm{Fe}$ (III)-reducers competed better in ethanol treatments where enhanced $\mathrm{U}(\mathrm{VI})$ removal was observed in parallel. Known MRP (Anaeromyxobacter, Geobacter, Clostridium, Pantoea) and NRP (Alcaligenes, Diaphorobacter, Dechloromonas, Arthrobacter, and Pseudomonas) were identified in microcosms and core samples using 16S rRNA gene analysis.

Our most recent work focused on analysis of mRNA targets to determine the metabolically active metal- and sulfate-reducing prokaryotes. High quality mRNA was extracted, reverse-transcribed, and cDNA amplified for dissimilatory (bi)sulfite reductase $(d s r A B)$ and citrate synthase $(g / t A)$ gene targets. For quantitative real-time PCR amplification of dsrA, degenerate primers were designed based on the nucleotide sequence homologies of DSR sequences from the $\mathrm{NCBI}$ database and the latest sequence data from the ORFRC (Bagwell et al., 2006). Degenerate primers targeting dsrAB were used for phylogenetic analysis of active sulfate reducers. Geobacter sp. have been implicated as an important MRP group in the ORFRC subsurface (North et al., 2004). Citrate synthase is a key enzyme for acetate catabolism, and one of the genes that codes for this enzyme ( $g / t A$ ) has been shown to be conserved across genomes of the Geobacteraceae family and its sequence is distinct from that of other microbial taxa. Thus, degenerate primers for Geobacteraceae gltA were modified and several new primers were designed on the basis of nucleotide sequences from the $G$. sulfurreducens, G. metallireducens, Desulfuromonas palmitatis, Pelobacter carbinolicus, $P$. propionicus genomes, and the above-mentioned Geobacter strain FRC-32. Both functional targets were successfully amplified from a range of sediments and MPN cultures sampled during the microcosm experiments. Preliminary phylogenetic analysis of partial gltA cDNA sequences indicates that clones from ORFRC subsurface sediments were most closely related to $G$. bemidjiensis, a strain that was isolated from hydrocarbon contaminated subsurface 2 
sediments. Surprisingly, other clones were affiliated to Desulfuromonas, suggesting that this may be a metabolically active metal-reducing group in ORFRC sediments.

Iron mineralogy. Iron minerals were extensively characterized in the radionuclide-contaminated saprolite of ORFRC subsurface over a range of contaminant levels using a battery of physical and wet chemical methods. In the course of investigating the speciation of Fe, we found that such complex samples require the acquisition of Mössbauer spectra over a wide temperature range (4 to $298 \mathrm{~K}$ ) in order to fully determine the various iron oxide phases (Stucki et al., 2007). The reason for this requirement is that Fe oxides often exist as an Al substituted phase and/or as a poorly crystallized (small particle size) phase, both of which are generally undetectable by Mössbauer spectroscopy at temperatures above $4 \mathrm{~K}$ and only the latter is dissolved by $\mathrm{HCl}$ and oxalate extractions. In the subsurface sediments we studied, we observed that a significant fraction of the $\mathrm{Fe}$ exists as Al-substituted goethite and undergoes magnetic ordering only below $12 \mathrm{~K}$, thus requiring the lowest temperatures possible. Our recently installed closed-cycle cryostat system is capable of sample temperatures as low as $4 \mathrm{~K}$.

Through examination of ORFRC biostimulated subsurface sediments from microcosms and field experiments (North et al., 2004; Sapp et al., 2006; Stucki et al., 2007), we determined that $\mathrm{Fe}$ in all of the ORFRC sediments studied was distributed in about equal quantities between aluminosilicates and Al-substituted goethite. In situ biostimulation dissolves as much as $30 \%$ of the goethite and transforms about half of the remainder to hematite, whereas aluminosilicate $\mathrm{Fe}$ (II) can be doubled without dissolution (Stucki et al., 2007). Silicate bound Fe(III) clearly predominated over the Fe minerals reduced.

\section{Summary of Conclusions to date. Isolates:}

$>$ Pure cultures were obtained from ORFRC subsurface sediments for at least four groups of anaerobic MRP including (Geobacter, Desulfotomaculum, Anaeromyxobacter, Clostridium).

$>$ Geobacter and Desulfotomaculum strains are physiologically distinct from close relatives. The Desulfotomaculum strain is capable of growth using both $\mathrm{Fe}(\mathrm{III})$ and sulfate.

$>$ The genome sequence of Geobacter strain FRC-32 is now available from JGI, and we have employed it's sequence in functional genomics as described above.

Microcosms/ Community Analysis:

$>\mathrm{pH}$ and redox (electron acceptor/donor availability) are master variables controlling not only the rates but also the pathways of microbial metabolism in the ORFRC subsurface.

$>$ Nitrate, $\mathrm{Fe}(\mathrm{III})$, and sulfate reduction are the predominant TEAPs.

$>$ The mechanism of $\mathrm{U}(\mathrm{VI})$ reduction appears to be electron donor dependent, with substantial reduction occurring prior to $\mathrm{Fe}(\mathrm{III})$ reduction in microcosms.

$>$ Phylogenetic analysis of cDNA from mRNA extracts of ORFRC sediments revealed clone sequences for gltA that are most closely related to Geobacter bemidjiensis and Desulfuromonas acetexigens.

$>$ Stable isotope probing with DNA targets was demonstrated for ORFRC sedments (see Task II).

$>$ The expression of key genes was quantified for anaerobic FRP and SRP groups in ORFRC sediments.

\section{Iron Mineralogy:}

$>$ Mössbauer spectroscopy supports wet chemical analyses and is reliable for identifying $\mathrm{Fe}$ oxide minerals only if measurements include temperatures as low as $4.2 \mathrm{~K}$.

$>$ Mössbauer analysis shows that phyllosilicates and goethite predominate in the ORFRC subsurface and equal or greater amounts of phyllosilicates are reduced during biostimulation in comparison to goethite 
Invited seminars, Meeting Abstracts, and Conference Presentations

2003

J. E. Kostka, D. L. Balkwill, J. W. Stucki. 2003. Impacts of Mineralogy and Competing Microbial Respiration Pathways on the Fate of Uranium in Contaminated Groundwater. DOE-NABIR Principal Investigator Meeting, 17-19 March.

N. North, L. Petrie, S. Dollhopf, D.L. Balkwill, and J.E. Kostka. 2003. Community Composition of Iron(III)-Reducing Bacteria from Subsurface Sediments of the Field Research Center. DOENABIR Principal Investigator Meeting, 17-19 March.

J. E. Kostka, N. North, E.M. Petrie, S.L. Dollhopf, D. L. Balkwill, J. W. Stucki. 2003. Characterization of Iron(III)-Reducing Microbial Communities from Acidic Subsurface Sediments Contaminated with Uranium at the U.S. DOE-NABIR Field Research Center (FRC). Annual Meeting of the American Society of Microbiology, Washington, DC, 18-22 May.

Kostka, J.E., L. Petrie, N. N. North, S.L. Dollhopf, D. L. Balkwill. 2003. Enumeration and Characterization of Iron(III)-Reducing Microorganisms from Acidic Subsurface Sediments For Development of Radionuclide Remediation Strategies. Biogeochemical Processes Involving Iron Minerals in Natural Waters, Monte Verita, Switzerland, November.

Chou, M.-I. M., S.-F. J. Chou, V. Patel, J. W. Stucki, and F. Botha. 2003. Production and testing of fired bricks made with class $\mathrm{F}$ fly ash from two Illinois coal-fired power plants. 15th International Symposium on Management \& Use of Coal Combustion Products (CCPs) by American Coal Ash Association, St. Petersburg, Florida., January 27-30.

Huo, D., C-I. Fialips, and J. W. Stucki. 2003. Effects of Structural Fe Oxidation State on Physicalchemical Properties of Smectites: Evidence from Infared Spectroscopy. Japanese Society of Soil Physics, Abstracts:10-11.

Lee, K. and J. W. Stucki. 2003. Structural distortions in Fe sites and reversibility of redox processes in Garfield nontronite: A Mössbauer Spectroscopic study. Annual Meeting of The Clay Minerals Society, Abstracts 2003: 99.

F. R. Ribeiro, J. W. Stucki, P. Komadel, J. D. Fabris, K. A. Marley, and R. A. Larson. 2003. Pesticide degradation by redox-modified smectites: Effects of $\mathrm{pH}$ and extent of Fe reduction. Annual Meeting of The Clay Minerals Society, Abstracts 2003: 133.

Sorensen, K. C., J. W. Stucki, M. J. Plewa, and R. E. Warner. 2003. Mammalian-cell Toxicity of Pesticides Treated with Redox-Modified Smectite. Annual Meeting of The Clay Minerals Society, Abstracts 2003: 147.

Li, O., W. F. Bleam, J. E. Kostka, J. W. Stucki, and K. Lee. 2003. Polarized EXAFS studies of nontronite reduced by anaerobic bacteria. Abstracts of Papers of the American Chemical Society 226: U492-U492 152-Envr Part 1 Sep 2003

Anastácio, A. A., J. D. Fabris, J. W. Stucki, P. R. C. Couceiro, F. S. Coelho, L. V. Rangel, and J. C. Ker. 2003. Caracterizacão de Argilominerais de um Chernossolo. Sociedade Brasileira de Química e Federacion Latinoamericana de Asociaciones Quimicas.

Sorensen, K. C. and J. W. Stucki. 2003. Effects of Fe oxidation state on the genotoxicity of pesticides to mammalian cells. Euroclay 2003, Abstracts: 261.

Stucki, J. W. and J. Cervini-Silva. 2003. Role of water on the fate of organics in reduced-smectite suspensions. Eos. Trans. AGU, 84(46), Fall Meet. Suppl., Abstract: B21B-0704.

Stucki, J. W. 2003. International Workshop on Biochemical Processes Involving Iron Minerals in Natural Waters, Monte Veritá, Conference Center, Ascona, Switzerland, November 16-21, 2003, Abstracts.

$\underline{2004}$ 
Kostka, J.E. 2004. "Interactions between Redox-active Microorganisms and Minerals in Soils and Sediments: Do We Know the Mechanisms?," Plenary address, Bouyoucos Conference, Soil Science Society of America, San Antonio, Texas, January.

J.W. Stucki and J.E. Kostka. 2004. Microbial Reduction of Iron in Smectite. Symposium on Abiotic and Biotic Electron Transfer Processes at Mineral Surfaces. Annual Meeting of the Soil Science Society of America, Seattle, November.

J.W. Stucki and J.E. Kostka. 2004. Biogeochemistry of Structural Iron at the Clay-water Interface. Symposium on the Biogeochemistry of the Cycle of Iron: Green Rusts and Fougerite, French Academy of Science, Paris, December.

J. E. Kostka, N. North, S. Dollhopf, L. Petrie, D. L. Balkwill. 2004. In Situ Change in Metal-reducing Bacteria and Other Members of the Sedimentary Microbial Community During Biostimulation of the Acidic Subsurface. Annual Meeting of the American Society of Microbiology, New Orleans, LA, May.

Cervini-Silva, J., R. A. Larson, and J. W. Stucki. 2004. Effect of interlayer cation on dehydrochlorination of polychlorinated ethanes by redox-manipulated smectite clay minerals. Annual Meeting of The Clay Minerals Society, Abstracts 2004: 41.

de Mello, J. W. V., J. W. Stucki, W. R. Roy, and J. L. Talbot. 2004. Arsenic mobilization and mineralogy of anomalous soils from Brazil. Annual Meeting of The Clay Minerals Society, Abstracts 2004: 55.

Lee, K., J. W. Stucki, and J. E. Kostka. 2004. Effects of bacterial reduciton of structural iron on the infrared spectra of iron-bearing smectites. Annual Meeting of The Clay Minerals Society, Abstracts 2004: 76.

Ribeiro, F. R., J. W. Stucki, P. Komadel, A. Banin, I. Negev, J. D. Fabris, K. A. Marley, R. A. Larson, and J. E. Kostka. 2004. Degradation of oxamyl by redox-modified smectites: Dissimilarities between chemical and bacterial reduction. Annual Meeting of The Clay Minerals Society, Abstracts 2004: 78.

Lee, K., J. W. Stucki, J. E. Kostka, and B. A. Goodman. 2004. Effects of in situ microbial stimulation on Fe phases in a sub-surfaces saprolitic soil: A variable-temperature Mössbauer spectroscopic study. Annual Meeting of The Clay Minerals Society, Abstracts 2004: 79.

Ribeiro, F. R., W. N. Mussel, J. D. Fabris, V. K. Garg, and J. W. Stucki. 2004. Iron-bearing compounds formed during aging of residues from industrial kaolin leaching: A variabletemperature Mössbauer spectroscopic study. Annual Meeting of The Clay Minerals Society, Abstracts 2004: 129.

$\underline{2005}$

Kostka, J.E. 2005. "Metal Reducing Microbial Communities in the Acidic Subsurface," University of Tubingen, Tubingen, Germany, March.

Kostka, J.E. 2005. "The Global Significance of Metal Reduction and Metal-Reducing Bacteria," Korea Ocean Research and Development Insitute, Seoul, Korea, May.

J. E. Kostka, H. Mills, L. Petrie, D. Akob, T. Gihring, D. L. Balkwill, J. W. Stucki, L. Kerkhof. 2005. Biostimulation of Iron Reduction and Uranium Immobilization: Microbial and Mineralogical Controls. DOE-NABIR Principal Investigator Meeting, Warrenton, VA, 18-20 April.

D. M. Akob, H. J. Mills, L. Edwards, D. L. Balkwill, J. E. Kostka. 2005. Metabolically-Active Microbial Communities in Acidic Uranium-Contaminated Subsurface Sediments. DOE-NABIR Principal Investigator Meeting, Warrenton, VA, 18-20 April.

D. M. Akob, H. J. Mills, L. Edwards, J. E. Kostka. 2005. The "Active" Microbial Communities found in Acidic Uranium-Contaminated Subsurface Sediments. Annual Meeting of the American Society for Microbiology, Atlanta, GA, June. 
T. M. Gihring, L. Edwards, M. E. Dollhopf, D. M. Akob, and J.E. Kostka. 2005. The Isolation and Characterization Of Novel, Metal-reducing Microorganisms From Uranium- and Nitratecontaminated Subsurface Sediments. Annual Meeting of the American Society for Microbiology, Atlanta, GA, June.

Cervini-Silva, J., R. A. Larson, and J. W. Stucki. 2005. Hydration/expansion and cation-charge compensation modulate the Brønsted basicity of adsorbed water in $\mathrm{Fe}(\mathrm{II})-\mathrm{Fe}$ (III) phyllosilicates. Proceedings of the 13th International Clay Conference, Tokyo, Japan, August 21-27.

$\underline{2006}$

Kostka, J.E. 2006. "Linking the structure and function of subsurface microbial communities for the assessment of bioremediation potential at the Oak Ridge Field Research Center," U.S. Department of Energy Environmental Remediation Sciences Program Fall Principal Investigator Meeting, Oak Ridge, Tennessee, October.

D. M. Akob, H. J. Mills, T. M. Gihring, and J. E. Kostka. 2006. Structure and Function of Metal- and Nitrate-reducing Microbial Communities in the FRC Subsurface. DOE-ERSP Principal Investigator Meeting, Warrenton, VA, 2-5 April.

J. E. Kostka, H. Mills, Denise Akob, T. Gihring, J. W. Stucki, B. A. Goodman, L. Kerkhof. 2006. Biostimulation of Iron Reduction and Uranium Immobilization: Microbial and Mineralogical Controls. DOE-ERSP Principal Investigator Meeting, Warrenton, VA, 2-5 April.

L. J. Kerkhof, D. Watson, J.E. Kostka, and L. McGuinness. 2006. Active Microorganisms in Groundwater Along a Contamination Plume at the Field Research Center in Oak Ridge, TN, USA. Annual Meeting of the American Society for Microbiology, Orlando, FL, May.

D. M. Akob, H. J. Mills, T. M. Gihring, L. Kerkhof, and J. E. Kostka. 2006. Structure and Function of Metal- and Nitrate-reducing Microbial Communities in Subsurface Sediments Contaminated with Radionuclides. Annual Meeting of the American Society for Microbiology, Orlando, FL, May.

F. Dittori, J.E. Kostka, J.D. Fabris, and J.W. Stucki. 2006. Comparisons of structural iron reduction in smectites by bacteria and dithionite: a variable-temperature Moessbauer spectroscopic study, Joint Meeting Groupe Francais des Argiles and The Clay Minerals Society, Poitiers, France, June.

O. Li, K. Lee, J. E. Kostka, J. W. Stucki, and William F. Bleam. 2006. Iron L-edge and K-edge X-ray absorption studies of nontronite reduction, $18^{\text {th }}$ World Congress of Soil Science, Philadelphia, Pennsylvania, July.

Dottori, F. R., J. E. Kostka, J. D. Fabris, and J. W. Stucki. 2006. Comparisons of structural iron reduction in smectites by bacteria and dithionite: a variable-temperature Mössbauer spectroscopic study. Annual Meeting of The Clay Minerals Society, Abstracts 2006: 80.

Stucki, J. W., B. Harris, J. D. Fabris, and A. S. Anastácio. 2006. Quantitative assay of minerals for $\mathrm{Fe}^{2+}$ and $\mathrm{Fe}^{3+}$ using 1,10-phenanthroline: IV. Advantages over and a critique of the Ferrozine method. Annual Meeting of The Clay Minerals Society, Abstracts 2006: 253.

Anastácio, A. S., F. Bergaya, J. D. Fabris, J. W. Stucki, and A. Aouad. 2006. Comparison of deferration methods for soils. Annual Meeting of The Clay Minerals Society, Abstracts 2006: 22.

Favre, F., M. Uchimiya, A. Stone, J. W. Stucki, and P. Boivin. 2006. Quinone as possible electron shuttles for the reduction of smectite structural iron. Annual Meeting of The Clay Minerals Society, Abstracts 2006: 90.

Stucki, J. W., K. Lee, B. A. Goodman, and J. E. Kostka. 2006. Effects of in situ biostimulation on iron mineral speciation in a sub-surface soil. Third Mid-European Clay Conference Abstracts, .

Komadel, P. and J. W. Stucki. 2006. Iron phases occurring in Fe-rich bentonite from Liekovec, Slovakia. Third Mid-European Clay Conference Abstracts. 
2007

Anastácio, A. S., D. M. Akob, J. E. Kostka, and J. W. Stucki. 2007. Iron reduction by biostimulation of contaminated soils: a Mössbauer spectroscopic study. Annual Meeting of The Clay Minerals Society, Abstracts 2007: 42.

Anastácio, A. S., A. Aouad, F. Bergaya, J. D. Fabris, and J. W. Stucki. 2007. Effects of dithionite methods on magnetic ordering in reduced ferruginous smectite. EuroClay 2007, Aveiro, Portugal, Abstracts.

Anastácio, A. S., A. Aouad, P. Sellin, F. Bergaya, and J. W. Stucki. 2007. Characterization of a redox-modified clay mineral with respect to its suitability as a barrier in radioactive waste confinement. Third International Conference on Natural and Engineered Clay Barriers for Radioactive Waste Confinement, Lille, France, Abstracts.

Publications

2003

North, N. 2003. Molecular characterization of the microbial community from uranium-contaminated acidic sediment to determine bioremediation potential at a U.S. Department of Energy site in Tennessee. M.S. Thesis, Florida State University, Department of Oceanography, 92 pp.

L. Petrie, N.N. North, S.L. Dollhopf, D.L. Balkwill, and J.E. Kostka. 2003. Enumeration and characterization of iron(III)-reducing microbial communities from acidic subsurface sediments contaminated with uranium (VI). Applied and Environmental Microbiology 69: 7467-7479.

H. Dong, J.E. Kostka, and J. Kim. 2003. Microscopic evidence for the microbial dissolution of smectite. Clays and Clay Minerals 51: 502-512.

Cervini-Silva, J., J. E. Kostka, R. A. Larson, J. W. Stucki, and Jun Wu. 2003. Promoted dehydrochlorination of 1,1,1,-trichloroethane and pentachloroethane by microbially reduced ferruginous smectite. Environmental Toxicology and Chemistry 22:1046-1050.

Cervini-Silva, J., R. A. Larson, J. Wu, and J. W. Stucki. 2003. Transformation of chlorinated aliphatic compounds by ferruginous smectite. Proceedings Twelfth International Clay Conference, Bahia Blanca, Argentina, 2001. pp. 241-246.

Sorensen, K. C., M. J. Plewa, and J. W. Stucki. 2003. Comparative quantitative analysis of agricultural chemicals using a microplate mammalian cell cytotoxicity assay. Bulletin of Environmental Contamination and Toxicology 70: 1083-1088.

$\underline{2004}$

N.N. North, S.L. Dollhopf, L. Petrie, J.D. Istok, D.L. Balkwill, and J.E. Kostka. 2004. A Change in Bacterial Community Structure During in situ Biostimulation of Subsurface Sediment Cocontaminated with Uranium and Nitrate. Applied and Environmental Microbiology 70: 49114920.

Sorensen, K. C., J. W. Stucki, R. E. Warner, and M. J. Plewa. 2004. Alternation of mammalian-cell toxicity of pesticides by structural iron(II) in ferruginous smectite. Environmental Science Technology 38:4383-4389. http://pubs.acs.org/cgi-bin/download.pl?es035151r/C5wS. See also Renner, Rebecca. 2004. Clays modify pesticide toxicity in soils. Environmental Science and Technology, Science News, July 7, 2004, for highlights of this article published by the ES\&T editorial staff (http://pubs.acs.org/subscribe/journals/esthag-w/2004/jul/science/rr_clays.html).

Huo, D., C-I. Fialips, L. Yan, and J. W. Stucki. 2004. Effects of structural Fe oxidation state on physical-chemical properties of smectites: evidence from infrared spectroscopy. Journal of the Japan Society of Soil Physics 96:3-9.

Swearingen, C., J. Wu, J. W. Stucki, and Alanah Fitch. 2004. Use of ferrocenyl surfactants of varying chain lengths to study electron transfer reactions in native montmorillonite clay. Environmental Science and Technology 38:5598-5603. 
Ribeiro, F.R., J.W. Stucki, R.A. Larson, K.A. Marley, P. Komadel, and J.D. Fabris. 2004. Degradation of oxamyl by redox-modified smectites: Effects of $\mathrm{pH}$, layer charge, and extent of reduction. Pp. 471-474 In Pecchio, M. et al. (Eds.), Applied Mineralogy, Developments in Science and Technology, Volume 1. ICAM 2004 Brazil, São Paulo.

Ribeiro, F.R., K. Lee, J.W. Stucki, and J.D. Fabris. 2004. Effects of redox reactions on the structure of Garfield nontronite: A Mössbauer spectroscopic study. Pp. 467-470. In Pecchio, M. et al. (Eds.), Applied Mineralogy, Developments in Science and Technology, Volume 1. ICAM 2004 Brazil, São Paulo.

$\underline{2005}$

Sorensen, K. C., J. W. Stucki, R. E. Warner, E. D. Wagner, and M. J. Plewa. 2005. Modulation of the genotoxicity of pesticides reacted with redox-modified smectite clay. Environmental and Molecular Mutagenesis 46:174-181.

de Mello, J.W.V., W.R. Roy, J.L. Talbott, and J.W. Stucki. 2005. Mineralogy and arsenic mobility in arsenic-rich brazilian soils and sediments. Journal of Soils and Sediments 6:9-19.

Edwards, L. 2005. Characterization of metal-reducing microbial communities from acidic subsurface sediments contaminated with uranium(VI), Doctoral Dissertation, Florida State University, Department of Oceanography, $94 \mathrm{pp}$.

$\underline{2006}$

Stucki, J. W. 2006. Iron redox processes in smectites. Chapter 8 In Bergaya, F., B. K. G. Theng, and G. Lagaly, (Eds.) Handbook of Clay Science, Elsevier, Amsterdam, pp. 429-482. (Acknowledgment of DOE-NABIR funding was included by the author but deleted by the publisher, who stated that no acknowledgments were to be included in any of the chapters.)

Stucki, J. W. and J. E. Kostka. 2006. Microbial reduction of iron in smectite. Compte Rendu, Geoscience 338:468-475

Lee, K., J. E. Kostka, and J. W. Stucki. 2006. Comparisons of structural iron reduction in smectites by bacteria and dithionite: An infrared spectroscopic study. Clays and Clay Minerals 54:197210.

Favre, F., J. W. Stucki, and P. Boivin. 2006. Redox properties of structural iron in ferruginous smectite. A discussion about the standard potential and its environmental implications. Clay and Clay Minerals 54:466-472

Favre, F., C. Bogdal, S. Gavillet, and J. W. Stucki. 2006. Changes in the CEC of a soil smectitekaolinite clay fraction as induced by structural iron reduction and iron coatings dissolution. Applied Clay Science 34:95-104.

Cervini-Silva, J., R.A. Larson, and J.W. Stucki. 2006. Hydration/expansion and cation charge compensation modulate the Brønsted basicity of distorted clay water. Langmuir 22: 2961-2965.

Michalson, M. M., B. A. Goodman, S. D. Kelly, K. M. Kemner, J. P. McKinley, J. W. Stucki, and J. D. Istok. 2006. Bio-immobilization of $\mathrm{U}(\mathrm{VI})$ and $\mathrm{Tc}(\mathrm{VII})$ in intermediate-scale physical models of an in situ bio-barrier. Environmental Science and Technology 40:7048-7053.

Lee, K., B. A. Goodman, J. E. Kostka, and J. W. Stucki. 2006. Changes in iron mineral speciation induced by biostimulation of a sub-surface soil. Geochimica et Cosmochimica Acta 71:835-843.

Komadel, P., J. Madejova, and J. W. Stucki. 2006. Structural Fe(III) reduction in smectites. Applied Clay Science 34:88-94.

Anastácio, A. S., J. D. Fabris, J. W. Stucki, F. S. Coelho, I. V. Pinto, and J. H. M. Viana. 2006. Clay fraction mineralogy of a Cambisol in Brazil. Hyperfine Interactions 166:619-624.

Mello J. W. V., W. R. Roy, J. L. Talbot, and J. W. Stucki. 2006. Mineralogy and arsenic mobility in arsenic-rich Brazilian soils and sediments. Journal of Soils and Sediments 6: 9-19. 
Mello, J. W. V., J. L. Talbot, J. Scott, W. R. Roy, and J. W. Stucki. 2006. Arsenic speciation in arsenic-rich Brazilian soils from gold mining sites under anaerobic incubation. Envronmental Science and Pollution Research. OnlineFirst <DOI:http://dx.doi.org/10.1065/espr2006.08.330>

$\underline{2007}$

D. M. Akob, H. J. Mills, D. L. Swofford, J. E. Kostka. 2007. Metabolically-Active Microbial Communities in Uranium-Contaminated Subsurface Sediments. FEMS Microbiology Ecology 59: 95-107.

L. Edwards, K. Kuesel, H. Drake, and J.E. Kostka. 2007. Electron flow in acidic subsurface sediments cocontaminated with nitrate and uranium during nuclear weapons production. Geochimica et Cosmochimica Acta 71: 643-654.

J. W. Stucki, K. Lee, B. A. Goodman, and J. E. Kostka. 2007. Effects of in situ biostimulation on iron mineral speciation in a sub-surface soil. Geochimica Cosmochimica Acta 71: 835-843.

Anastácio, A. S., A. A. Aouad, P. Sellin, F. Bergaya, J. D. Fabris, and J. W. Stucki. 2007. Characterization of a redox-modified clay mineral with respect to its suitability as a barrier in radioactive waste confinement. Applied Clay Science (In Press). 